\title{
Extracts from Ministerial Statements
}

The disparity in wealth between the richer nations of the world-many of them outside Europe, some of them in the Group of 77-and the poorer must be diminished. It is contrary to the principles of human dignity which underlie our own European civilisation. It provides opportunities for the enemies of freedom to extend their influence. It impedes the development of trade and this can only be to the disadvantage of all since, in the last analysis, the prosperity of any nation depends on its ability to trade successfully.

It is therefore both morally and economically right that we should help the countries of the Third World to help themselves. The practical assistance which they need can and should take many forms and flow through many channels, both public and private. Our aim is to assist them to develop their economies, to exploit their resources and to educate their people. Where we can, we must also play our part in trying to resolve the burning political issues-both local and regional-which divert them from their other pressing tasks.

\section{Speech by the Prime Minister Margaret Thatcher Bordeaux, 19 September 1980}

Nowhere can the Brandt Report have been read with greaterinterest than in Britain. It has been the publishing success of the year, and at the last count had sold ten times as many copies as in the United States. It has been debated vigorously in Parliament and in the Press. There has been a lively but very healthy controversy about the ways in which we should respond to it.

It is encouraging that British public opinion should take these issues so seriously. There is no disposition to pull up the drawbridge, ensconced in our oil-rich, technologically-advanced fortress and hope that the world's problems will simply go away. We know that they won't.

We also know that, as a leading British newspaper put it only yesterday, soft words are not enough. Indeed the British Government has been taken to task because we have not indulged in extensive rhetoric on this immensely important subject. We have not done so because we believe that concern, sympathy and rhetoric are not enough. Because we believe that careful thought and thorough preparation must be given to measures designed to tackle the strains and imbalance in the world's economic system.

Above all, because we believe it is not rhetoric which is required, but action.

\section{Speech by the Foreign Secretary Lord Carrington Caracas, 4 August 1980}

\section{The need to reform the world economic system}

Q. Is not there a major difference between the Government and the Brandt Commission with regard to the functioning of the world economic system? Is not the Government's attitude that by and large this is a pretty good system and needs some adjustments from time to time to cope with the oil crisis and the problems of the developing countries but it does not really require fundamental restructuring, whereas the Brandt Commission does make it clear in many places that what is needed is a fundamental, structural change in the present world economic system and while one does not want to over-emphasise this, it does seem to be a basic difference between the Government's approach and that of the Brandt Commission.

Mr. Hurd: There is no particular difference here between ourselves and the other main, industrialised countries; we do regard the present institutions as more flexible and capable of greater change than perhaps, by implication, the authors of the Brandt Report do. We are, to use the time-honoured phrase, evolutionary rather than revolutionary. We are a little distrustful of simply multiplying meetings and machinery. There is no shortage of meetings all round this set of subjects. They are very numerous and there is no shortage of machinery and institutions. We do think, that evolution, change, flexibility are evident, in the record so far and because we think it is evident, that is the way we think the institutions should develop rather than saying no good, scrap it, put it on the sidelines, start with something else. Brandt did not actually say scrap it, start with something else but one does get this flavour sometimes in some of the proposals which are made.

...

There is a great deal going on. I have here a list of the changes taking place in the Bank and the Fund. The Fund's compensatory financing facility, for example,

Bulletin. 1981, vol 12 no 2. Institute of Development Studies. Sussex 
has been enlarged and modified and 85 bn has been drawn in the last four and a half years. I mentioned the doubling of the capital of the World Bank: I mentioned the IDA replenishment. The World Bank has embarked on a new programme for structural adjustment lending. Agreement has been reached to increase IMF quotas by 50 per cent etc. The picture is of a series of existing institutions which are not stagnant and inactive. They are alive and responsive and changing quite fast. There will alway's be arguments that they should do more and I think one result of the present kind of discussion going on through the world is that they will be pressed to do more and that when they meet next month and thereafter. they will accelerate their consideration of the kind of proposals we are talking about.

\section{Minister of State, Mr. Douglas Hurd Evidence to House of Commons Foreign Affairs Committee 5 August 1980}

Mr. Hurd: It would surely be a mistake to launch on a global round on a basis which ensured, as it were, that it foundered or failed to make progress. It is worth taking trouble over the procedures. Three countries of substance in this argument, the United States, Germany and Britain, were not happy with the text which emerged from the special session because we thought that the procedures proposed for the global round would or might undermine the autonomy and thus the effectiveness of the international financial institutions. We did not think that it was sensible, from anyone s point of view, that the institutions - the IMF, the World Bank and so on-should be put in a position in which they were subordinated to the General Assembly and virtually given instructions by it.

Mr. Douglas Mann: In August 1980 the World Bank commented that of all the industrialised countries, the only ones that were not increasing aid as a proportion of their gross national products were Britain and Canada. Perhaps as a result of the general election Canada is now increasing the amount of aid that it gives as a proportion of its gross national product. This country is one of the few to have its own oil resources and a rising balance of payments surplus. Why cannot we increase our aid contribution as a proportion of gross national product?

Mr. Hurd: I can explain that only by giving a lecture on our general economic situation. The decision on aid was taken not because we dislike aid. but because of the general constraints on public spending which in turn are part of our economic policy.

Speech by Mr. Douglas Hurd House of Commons, 12 December 1980
I should like here to say a word about our own policy. The overriding objective of my Government is the reduction of inflation. But in giving priority to this aim, in concentrating on putting our economy right, we are not taking a selfish view. On the contrary, a sound economy can be the only basis for a substantial long-term aid programme, to which we have been, and continue to be, committed. It is not always realised. even domestically, that only four donor countries in the developed world provide a larger volume of aid in absolute terms than the UK. Only six developed country donors provide a higher relative proportion of GNP than ourselves. Last year two-thirds of our bilateral programme was directed to the poorest countries. We also make a substantial contribution to multilateral aid, including a 10 per cent share of the sixth replenishment of the IDA, amounting to $\$ 555 \mathrm{mn}$. In this respect we have done our best to adjust our programme to the changed circumstances of the later 1970s and the 1980s.

We also believe that restoration of our economy will enlarge trading opportunities for developing countries. Their. earnings from trade are over ten times their receipts from aid, and. without enlarged trading opportunities. the benefits fromaid-financed investment can be blocked.

Speech by the Minister of Overseas Development Mr Nell Marten UN Special Session, 27 August 1980

There have been claims in the press that the Government have failed to respond to the challenge of the Brandt Report and even that we have dismissed the Report and its findings. This is not so. We welcome the Report and the attention which it has drawn to the serious world economic situation expected for the I980s. We agree with the Report's view that too many people in the world still live in poverty, exposed to hunger, disease, homelessness, and natural disasters. We recognise the seriousness of the outlook for the developing countries, faced with the immediate problems of trying to cope with increased oil prices and indebtedness. Indeed, we share the view of the Brandt Commission that the IMF and the World Bank should play a larger role in helping developing countries to overcome their present difficulties.

The Brandt Commission stressed the importance of increasing the trade flows of developing countries. As a member of the European Community, we have participated in arrangements under the Lomé Convention designed to achieve this.

The Brandt Report included a proposal for a NorthSouth Summit, limited in numbers, to try to give fresh 
political impetus to international efforts on the whole range of development issues. The Government has already expressed its willingness to participate in such a Summit.

Speech by the Minister for Overseas Development Mr Neil Marten at Church of England Board for Social Responsibility 19 November 1980

I do not underestimate the size of the task facing the international community. Nor, however, do I believe that we should be despondent. In recent vears there have been a number of steps in the right direction such as the Common Fund for commodities, the new arrangements in the IMF designed to benefit developing countries; and the liberalisation of world trade through the GATT Tokvo round.
Looking to the future there are clearly areas in which action needs to be put in hand rapidly. These include population growth: further agricultural research and investment: improved access to markets; and, not least, emphasis on controlling inflation, which has plaved a part in inhibiting trade and investment and stifling growth in developing countries.

An international debate of unprecedented scope and seriousness has been launched. In a world in which some $800 \mathrm{mn}$ people live in absolute poverty, we all have an obligation to see that this debate produces results.

Speech by the Foreign Secretary Lord Carrington Mexico City, 6 August 1980 